\title{
Signal beyond nutrient, fructose, exuded by an arbuscular mycorrhizal fungus triggers phytate mineralization by a phosphate solubilizing bacterium
}

\author{
Lin Zhang ${ }^{1,2} \cdot$ Gu Feng ${ }^{1} \cdot$ Stéphane Declerck ${ }^{2}$
}

Received: 20 January 2018 / Revised: 18 March 2018 / Accepted: 20 March 2018 / Published online: 13 June 2018

(c) The Author(s) 2018. This article is published with open access

\begin{abstract}
Cooperation is a prevalent phenomenon in nature and how it originates and maintains is a fundamental question in ecology. Many efforts have been made to understand cooperation between individuals in the same species, while the mechanisms enabling cooperation between different species are less understood. Here, we investigated under strict in vitro culture conditions if the exchange of carbon and phosphorus is pivotal to the cooperation between the arbuscular mycorrhizal fungus (AMF) Rhizophagus irregularis and the phosphate solubilizing bacterium (PSB) Rahnella aquatilis. We observed that fructose exuded by the AMF stimulated the expression of phosphatase genes in the bacterium as well as the rate of phosphatase release into the growth medium by regulating its protein secretory system. The phosphatase activity was subsequently increased, promoting the mineralization of organic phosphorus (i.e., phytate) into inorganic phosphorus, stimulating simultaneously the processes involved in phosphorus uptake by the AMF. Our results demonstrated for the first time that fructose not only is a carbon source, but also plays a role as a signal molecule triggering bacteria-mediated organic phosphorus mineralization processes. These results highlighted the molecular mechanisms by which the hyphal exudates play a role in maintaining the cooperation between AMF and bacteria.
\end{abstract}

\section{Introduction}

How species adapt to their environment to survive and reproduce is a central question in ecology. Some organisms favor selfish acts in order to maintain a competitive advantage [1], while others engage in a wide range of cooperative behaviors from cooperation between genes to cooperation between communities [2]. Yet, cooperation remains the least known, and several theories, e.g. kin

Electronic supplementary material The online version of this article (https://doi.org/10.1038/s41396-018-0171-4) contains supplementary material, which is available to authorized users.

Gu Feng

fenggu@cau.edu.cn

1 College of Resources and Environmental Sciences; Research Center for Resources, the Environment and Food Safety, China Agricultural University, 100193 Beijing, China

2 Université catholique de Louvain, Earth and Life Institute, Applied Microbiology, Mycology, Croix du sud 2, bte L7.05.06, 1348 Louvain-la-Neuve, Belgium selection, reciprocity..., have been explored by scientists [3].

The association between plants and arbuscular mycorrhizal fungi (AMF), that goes back more than 450 million years [4], represents a suitable model for studying the cooperation between unrelated species [5, 6]. AMF produce substantial hyphae biomass in soil (between 45 and $100 \mathrm{~m}$ mycelium per gram of soil in prairies and pastures [7]) and recruit various genera of bacteria on its surface $[8,9]$. For instance, phosphate solubilizing bacteria (PSB) involved in the mineralization of organic phosphates have been detected on the AMF hyphae surface [10,11]. Via their metabolism, inorganic $\mathrm{P}$ is released and exchanged for plant-derived carbohydrates exuded by hyphae [12-14]. If it is unanimously accepted that hyphae exudates provide nutrients to the microbes developing in their close vicinity [15], then the mechanisms by which exudates may stimulate phosphorus mineralization by bacteria are still unknown, as well as the potential candidate signaling compounds.

The pivotal role of sugars as signaling molecules in microorganisms has been widely illustrated. For example, UDP-glucose is a potential intracellular signal molecule in the control of expression of sigma $\mathrm{S}$ and sigma S-dependent 
genes in Escherichia coli [16]. Fructose metabolism has been reported to affect cellular processes such as biofilm formation by streptococci and bacterial pathogenicity in plants [17]. Trehalose is able to regulate the bacterial community composition [13].

Interestingly, in the symbiotic association between plants and AMF, it has been shown that the plants release sucrose into the peri-arbuscular space, which is then hydrolyzed to fructose and glucose. Both hexoses are probably transferred inside the arbuscules, though this needs to be demonstrated firmly [18]. In parallel, it has been reported that the intraradical hyphae of AMF can take up exogenous glucose and fructose directly [19-21]. Both are major sugars of root exudates [22]. Part of the hexoses is then synthetized to glycogen in the intraradical hyphae and further transported to the extraradical hyphae where is it converted into trehalose [18]. However, it cannot be ruled out that part of the glucose and fructose is not converted and remains under these forms in the extraradical hyphae. Trehalose, glucose, and fructose may thus be important sugars inside the extraradical hyphae which could be potentially released outside the hyphae. Interestingly, these three sugars were reported in hyphal exudates of Rhizophagus irregularis MUCL 41833 [23], even though the authors could not firmly exclude that their presence was due to diffusion from the roots. Furthermore, no information was available on the concentration of these sugars in the hyphosphere and whether they could represent candidate signaling compound that might trigger the C-P exchange process between AMF and PSB.

In the present study, we investigated whether fructose, glucose, and trehalose are present in the hyphal exudates of $R$. irregularis MUCL 43194 and if they are potential candidate signaling compounds to prime the processes related to metabolism of cell and phosphatase production in the PSB Rahnella aquatilis HX2. More specifically, we addressed the following hypotheses: (1) AMF hyphal exudates contain sugars, which are preferentially assimilated by the bacteria, (2) the expression of genes encoding bacterial phosphatase production and excretion increase concomitantly with the uptake of specific sugars, (3) the genes involved in the processes of phosphate transfer and polyP synthesis in the extraradical hyphae of the AMF are enhanced by the presence of the bacteria.

\section{Materials and methods}

\section{Biological material}

The AMF strain used was $R$. irregularis (Błaszk., Wubet, Renker \& Buscot) C. Walker \& A. Schüßler as "irregulare" MUCL 43194. The fungus was maintained in root organ cultures (ROC) of carrot (Daucus carota L.). The PSB strain used was $R$. aquatilis strain HX2. This strain has been wholegenome sequenced [24] and was shown effective in the mineralization and utilization of phytate $\mathrm{P}$ [15]. Two plants were used: ROC of Daucus carota L. clone DC2 and whole plants of Medicago truncatula L. Gaertn. cv. Jemalong A17 (SARDI, Australia) prepared as in Buysens et al. [25].

\section{Gene analysis}

The whole-genome sequence of $R$. aquatilis is available at the National Center for Biotechnology Information (NCBI) (GenBank assembly accession: GCA_000255535). Three putative sugar (i.e., fructose, glucose, and trehalose) transporters of $R$. aquatilis were selected. More than ten phosphatases were found in $R$. aquatilis, but only the excretive ones can play a role in organic $\mathrm{P}$ hydrolyzation in the soil. Because the excretive proteins have a short terminal signal peptide and transmembrane domains, SignalP 4.1 software (http://www.cbs.dtu.dk/services/SignalP) and TMHMM V2.0c program (http://www.cbs.dtu.dk/services/TMHMM/) were used to predict the excretive phosphatases. Finally, one phytase, three acid phosphatases, and one alkaline phosphatase, as well as two key proteins in cell division of $R$. aquatilis and two proteins in type II and IV secretory system, were selected. The primers for the genes of the above selected proteins or their subunits were designed by Primer 5. The sequences of primers and other information related to the selected genes are reported in Table S1.

\section{Experiment 1: fructose, glucose, and trehalose exudation by hyphae of $R$. irregularis}

Bi-compartmented Petri plates $(90 \times 15 \mathrm{~mm})$ were used to grow the excised transformed carrot roots and AMF as detailed in St-Arnaud et al. [26] (see Methods in supplementary information) with minor modification: $5 \mathrm{ml}$ MSR medium was removed with a sterilized scalpel along the plastic barrier in the root compartment (RC) to avoid diffusion of sugars from RC to hyphal compartment (HC) (see Fig. S1). Three treatments were considered: absence of mycorrhizal roots in the $\mathrm{RC}$ and $R$. irregularis in the $\mathrm{HC}$ $\left(\mathrm{RC}^{-\mathrm{MR}} / \mathrm{HC}^{-\mathrm{RI}}\right)$; presence of mycorrhizal roots in the $\mathrm{RC}$ but without proliferation of $R$. irregularis in the HC (RC ${ }^{+\mathrm{MR}} / \mathrm{HC}^{-\mathrm{RI}}$ ); presence of mycorrhizal roots in the $\mathrm{RC}$ and proliferation of $R$. irregularis in the $\mathrm{HC}\left(\mathrm{RC}^{+\mathrm{MR}} / \mathrm{HC}^{+\mathrm{RI}}\right)$. Each treatment consisted of four replicates.

At week 7, the extraradical mycelium (ERM) of AMF in the $\mathrm{RC}^{+\mathrm{MR}} / \mathrm{HC}^{+\mathrm{RI}}$ treatment developed extensively on the slope of the HC. Ten milliliters of liquid MSR medium without $\mathrm{Ca}\left(\mathrm{NO}_{3}\right)_{2} \cdot 4 \mathrm{H}_{2} \mathrm{O}$, sucrose, and vitamins but containing $280 \mu \mathrm{M}$ phytate-P (Na-phytate, Sigma-Aldrich, St Louis, USA) was added in the HC to allow the growth of ERM. The ERM extended from the slope into the whole 
$\mathrm{HC}$. The same liquid MSR medium was used in the $\mathrm{RC}^{-\mathrm{MR} /}$ $\mathrm{HC}^{-\mathrm{RI}}$ and $\mathrm{RC}^{-\mathrm{MR}} / \mathrm{HC}^{-\mathrm{RI}}$ treatments.

After another 4 weeks, the HC was covered by actively growing hyphae. The MSR medium was then collected, passed through an Acrodisc ${ }^{\circ}$ Syringe Filter and stored at $-20^{\circ} \mathrm{C}$ until analysis. The hyphae remaining in the $\mathrm{HC}$ were cleaned three times with sterilized deionized water, collected and weighed, and the content was extracted as described by Duan et al. [27] (see Methods in supplementary information). The presence and concentration of fructose, glucose, and trehalose in the hyphal extract and the collected medium was determined by their respective standard sample (J\&K Scientific Ltd., Beijing, China) using ICS-3000 Ion Chromatography System (Dionex, California, USA) [28]. For the analysis of sugars in the hyphal exudates, the $\mathrm{RC}^{-\mathrm{MR}} / \mathrm{HC}^{-\mathrm{RI}}$ treatment was used as the control, the $\mathrm{RC}^{+\mathrm{MR}} / \mathrm{HC}^{-\mathrm{RI}}$ treatment to test whether there is an influence of volatile compounds produced by roots and mycorrhizal hyphae, and the $\mathrm{RC}^{+\mathrm{MR}} / \mathrm{HC}^{+\mathrm{RI}}$ treatment to collect the hyphal exudates.

\section{Experiment 2: Impact of $R$. irregularis on metabolism and phosphatase production in $R$. aquatilis}

Three treatments $\left(\mathrm{RC}^{-\mathrm{MR}} / \mathrm{HC}^{-\mathrm{RI}}, \mathrm{RC}^{+\mathrm{MR}} / \mathrm{HC}^{-\mathrm{RI}}\right.$, and $\mathrm{RC}$ $+\mathrm{MR} / \mathrm{HC}^{+\mathrm{RI}}$ ) with four replicates were set up as in experiment 1 , but without removing $5 \mathrm{~mm}$ MSR medium in the RC. At week 11, the HC was covered by the ERM. The remaining liquid MSR medium ( $\pm 9 \mathrm{ml}$ ) was transferred to a $15-\mathrm{ml}$ tube and adjusted to $10 \mathrm{ml}$ using the same liquid MSR medium as above but without phytate-P. Two milliliters of bacteria at a concentration of approximately $10^{8} \mathrm{CFUs} \mathrm{ml}^{-1}$ was added and mixed uniformly. The $12 \mathrm{ml}$ MSR medium was then added to the $\mathrm{HC}$ of each experimental system in contact with the ERM. The supernatant of bacteria was also added in the $\mathrm{RC}^{-\mathrm{MR}} / \mathrm{HC}^{-\mathrm{RI}}$ and $\mathrm{RC}^{-\mathrm{MR}} / \mathrm{HC}^{-\mathrm{RI}}$ treatments following the same procedure (see Fig. S2).

At $1,6,12,24,48$, and $72 \mathrm{~h}, 0.5 \mathrm{ml}$ medium was sampled and added to $1 \mathrm{ml}$ RNAprotect ${ }^{\circledR}$ Bacteria Reagent (Qiagen) before storage at $-80{ }^{\circ} \mathrm{C}$ for RNA extraction. At final harvest (i.e., $72 \mathrm{~h}$ ), the remaining medium $( \pm 9 \mathrm{ml})$ in the $\mathrm{HC}$ was passed through an Acrodisc ${ }^{\circledR}$ Syringe Filter (0.2 $\mu \mathrm{m}$ Supor ${ }^{\circledR}$ Membrane, Pall Corporation, New York, USA), to remove the bacterial cells, and stored at $-20{ }^{\circ} \mathrm{C}$ for analysis of inorganic and total $\mathrm{P}$. Inorganic $\mathrm{P}$ concentration was determined by the molybdenum blue method [29]. Total $\mathrm{P}$ concentration was evaluated by inductively coupled plasma atomic emission spectroscopy (ICP-AES). Phytate-P concentration was then calculated by subtracting the inorganic $\mathrm{P}$ from the total $\mathrm{P}$ concentration. Determination of acid and alkaline phosphatase activity (pKatal $\mathrm{ml}^{-1}$ medium) was conducted according to Neumann [30].
Total RNA was extracted from the frozen bacterial cells using the RNeasy ${ }^{\oplus}$ Mini Kit (Qiagen), according to the manufacturer's instructions and treated with TURBO DNAfree $^{\mathrm{TM}}$ Kit (Ambion) to remove the possible DNA contamination. For single-strand cDNA synthesis, $300 \mathrm{ng}$ of total RNA was reverse-transcribed at $65^{\circ} \mathrm{C}$ for $10 \mathrm{~min}, 55^{\circ}$ $\mathrm{C}$ for $20 \mathrm{~min}$, and $85^{\circ} \mathrm{C}$ for $5 \mathrm{~min}$ in a final volume of $20 \mu \mathrm{l}$ containing $1 \mu \mathrm{l}$ random primer using Transcriptor High Fidelity cDNA Synthesis Kit (Roche). The products were then diluted to $100 \mu \mathrm{l}$.

Quantitative RT-PCR (qRT-PCR) was performed using a LightCycler $^{\circledR} 96$ Real-Time PCR System (Roche). Each PCR reaction was carried out in a total volume of $10 \mu \mathrm{l}$ containing $2.5 \mu \mathrm{l}$ cDNA, $5 \mu \mathrm{l} 2 \times$ FastStart Essential DNA Green Master (Roche), and $0.5 \mu$ l of each primer $(5 \mu \mathrm{M})$. The following PCR program was used: $95^{\circ} \mathrm{C}$ for $600 \mathrm{~s}, 45$ cycles of $95^{\circ} \mathrm{C}$ for $10 \mathrm{~s}, 60^{\circ} \mathrm{C}$ for $10 \mathrm{~s}, 72^{\circ} \mathrm{C}$ for $10 \mathrm{~s}$. A melting curve was recorded at the end of each run to exclude the generation of non-specific PCR products [31]. All reactions were performed on three technical replicates. Baseline range and threshold cycle $(\mathrm{Ct})$ values were calculated using LightCycler ${ }^{\circledR} 96$ software. The $\Delta \mathrm{Ct}$ was calculated by subtracting the $\mathrm{Ct}$ value of a reference gene from the $\mathrm{Ct}$ value of each target gene. Relative change fold of each target gene was normalized by $2^{-\Delta \Delta \mathrm{Ct}}$ method, referring to the $\Delta \mathrm{Ct}$ value in the $\mathrm{RC}^{-\mathrm{MR}} / \mathrm{HC}^{-\mathrm{RI}}$ treatment harvested at the 1-h sampling time. The constitutively expressed RNA polymerase sigma factor RpoD was used as a house-keeping gene.

\section{Experiment 3: Relationship between phosphatase gene expression and uptake of fructose and glucose in $R$. aquatilis}

Ten milliliters of liquid MSR medium (without $\mathrm{Ca}\left(\mathrm{NO}_{3}\right)$ ${ }_{2} \cdot 4 \mathrm{H}_{2} \mathrm{O}$, sucrose, and vitamins $)$ without fructose $(0 \mu \mathrm{M})$ or supplemented with $5,20,100 \mu \mathrm{M}$, and $1 \mathrm{mM}$ of fructose and with $20 \mu \mathrm{M}$ glucose was mixed with $2 \mathrm{ml}$ bacterial suspension of $R$. aquatilis (optical density, $\mathrm{OD}_{600}=0.8$ ). The mixed solution was poured into one of the compartments of the bi-compartmented Petri plates and cultured at $27^{\circ} \mathrm{C}$. After 1 and $6 \mathrm{~h}$, the bacterial cells were harvested and the total RNA was extracted. The expression of putative fructose transporter gene fruT and phosphatase genes acpl and alp were determined. The preparation of bacterial suspension, RNA extraction, genes expression determination, and analyses were as described in experiment 2 .

\section{Experiment 4: Influence of fructose and glucose on growth and phosphatase activities of $R$. aquatilis}

Similar to experiment $3, R$. aquatilis was cultured in the absence of fructose or in the presence of 5, 20, $100 \mu \mathrm{M}$, and 
$1 \mathrm{mM}$ of fructose and glucose. At $6,12,24,48$, and $72 \mathrm{~h}$, $0.5 \mathrm{ml}$ medium was sampled and the OD was measured at $590 \mathrm{~nm}$ using an iMark $^{\mathrm{TM}}$ Microplate Reader (Bio-Rad, Hercules, CA, USA). At $7 \mathrm{~d}$, the remaining medium was passed through an Acrodisc Syringe Filter to remove the bacterial cells and determine the acid and alkaline phosphatase activities.

\section{Experiment 5: Influence of $R$. aquatilis on gene expression in the extraradical hyphae of $R$. irregularis}

An autotrophic in vitro culture system was used (adapted from Voets et al. [32]) (see Methods in supplementary information). Starting from week 3 after transfer of the plantlets, $10 \mathrm{ml}$ MSR medium, lacking sucrose and vitamins, and cooled to $40^{\circ} \mathrm{C}$, was added weekly to the RC. At week 9, when a profuse ERM was growing on the slope, 10 ml liquid MSR medium without $\mathrm{Ca}\left(\mathrm{NO}_{3}\right)_{2} \cdot 4 \mathrm{H}_{2} \mathrm{O}$, sucrose, and vitamins, but containing $280 \mu \mathrm{M}$ phytate-P, was added to the HC. During the following 4 weeks, $3 \mathrm{ml}$ of the same liquid MSR medium, but without phytate-P, was added twice a week.

At week 13, a profuse ERM covered the HC. Three systems with AMF-colonized plantlets and three control systems with non-mycorrhizal plantlets were selected. The liquid MSR medium in the HC was transferred to a 15-ml tube and adjusted to $10 \mathrm{ml}$ using the same liquid MSR medium as above, but without phytate-P. Two milliliters of bacteria at a concentration $\pm 10^{8} \mathrm{CFUs} \mathrm{ml}^{-1}$ was added and mixed uniformly. The $12 \mathrm{ml}$ MSR medium containing the bacteria was added to the HC of each system. Three additional systems with AMF-colonized or non-colonized plantlets were similarly selected and $2 \mathrm{ml}$ liquid MSR medium without $R$. aquatilis was added to the HC. Four treatments were thus considered: absence of $R$. irregularis and $R$. aquatilis in the HC (-RI-RA); absence of $R$. irregularis, but with $R$. aquatilis in the $\mathrm{HC}(-\mathrm{RI}+\mathrm{RA})$; presence of $R$. irregularis but without $R$. aquatilis in the $\mathrm{HC}$ (+RI-RA); presence of both $R$. irregularis and $R$. aquatilis in the $\mathrm{HC}(+\mathrm{RI}+\mathrm{RA})$. Three replicates were considered per treatment (see Fig. S3).

The liquid MSR medium containing $R$. aquatilis was added in the $\mathrm{HC}$ in contact with the ERM. After $6 \mathrm{~h}, 0.5 \mathrm{ml}$ medium was sampled and added to $1 \mathrm{ml}$ RNAprotect ${ }^{\circ}$ Bacteria Reagent (Qiagen) according to the handbook to stabilize the bacterial RNA. The samples were then stored at $-80{ }^{\circ} \mathrm{C}$ until RNA extraction. The expressions of sugar transporter and phosphatase genes were determined. The preparation of bacterial suspension, RNA extraction, gene expression determination, and analyses were as described in experiment 2 .

The ERM was collected, poured into a 2-ml tube and stored at $-80{ }^{\circ} \mathrm{C}$. The frozen fungal material was ground using MagNA Lyser (Roche) and the total RNA extracted using the RNeasy ${ }^{\oplus}$ Plant Mini Kit (Qiagen), according to the manufacturer's instructions and treated with TURBO DNAfree $^{\mathrm{TM}} \mathrm{Kit}$ (Ambion) to remove the possible DNA contamination. For single-strand cDNA synthesis, $150 \mathrm{ng}$ of total RNA was reverse-transcribed at $65^{\circ} \mathrm{C}$ for $10 \mathrm{~min}, 55^{\circ}$ $\mathrm{C}$ for $20 \mathrm{~min}$, and $85^{\circ} \mathrm{C}$ for $5 \mathrm{~min}$ in a final volume of $20 \mu \mathrm{l}$ containing $1 \mu \mathrm{l}$ Oligo (dT) primer using Transcriptor High Fidelity cDNA Synthesis Kit (Roche). The products were then diluted to $60 \mu \mathrm{l}$. The qRT-PCR was performed to determine the phosphate transporter gene GintPT and polyP synthesis gene Vtc4p [33]. Transcript levels were normalized to the Ct value of GintEFla [34]. The program was similar to experiment 2.

The remaining medium in the $\mathrm{HC}$ was passed through an Acrodisc ${ }^{\circ}$ Syringe Filter to remove the bacterial cells and stored at $-20^{\circ} \mathrm{C}$ for analysis of inorganic $\mathrm{P}$ concentration by the molybdenum blue method.

\section{Data analysis}

Statistical analyses were performed using SPSS v. 16.0 (SPSS Inc., Chicago, IL, USA). In experiment 1, significant differences $(P<0.05)$ among three sugar concentrations in the hyphal exudates were evaluated by a Tukey's honest significant difference (HSD) test. In experiment 2, one-way ANOVA was conducted to compare the effect of AMF on acid and alkaline phosphatase activities, inorganic $\mathrm{P}$ concentration, and phytate-P concentration. Significant differences $(P<0.05)$ among three inoculation treatments were evaluated by a Tukey's HSD test. Two-way ANOVA was conducted to compare the effects of harvest time (Time), AMF, and their interaction on expression of putative sugar transporter genes fruT and gluT; phosphatase genes phy, acp1, acp2, acp3, and alp; key genes in cell division $f t s A$ and $f t s Z$, and genes $g s p F$ and $v i b 8$ involved in type II and IV secretory system. In experiments 3 and 4 , significant differences $(P<0.05)$ among the treatments were evaluated by a Tukey's HSD test. In experiment 5, significant differences in gene expression between two inoculation treatments were evaluated by a $t$-test.

\section{Results}

\section{Experiment 1: Fructose, glucose, and trehalose exudation by hyphae of $R$. irregularis}

Fructose, glucose, and trehalose were detected both inside the extraradical hyphae developing in the $\mathrm{HC}$ and in the hyphal exudates. In hyphae, their concentrations were, respectively, $75.6 \pm 32.8,263.9 \pm 106.7$, and $188.6 \pm 84.5$ 


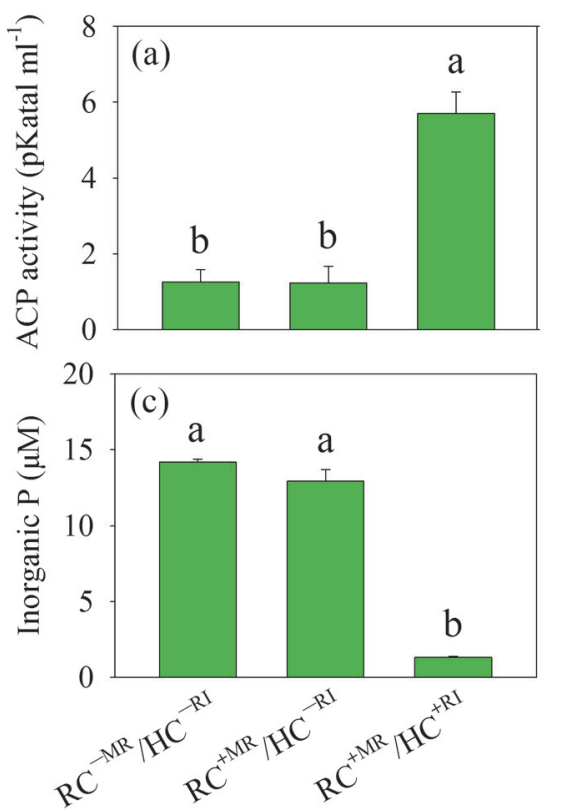

Fig. 1 a Acid phosphatase (ACP) activity, b alkaline phosphatase (ALP) activity, $\mathbf{c}$ inorganic $\mathrm{P}$ concentration, and $\mathbf{d}$ phytate-P concentration remaining in the liquid MSR medium harvested from the $\mathrm{HC}$ of the Petri plate in experiment 2. Histograms with the same letter do not differ significantly ( $P \geq 0.05$; Tukey's HSD test; $n=4)$. RC ${ }_{-\mathrm{MR}}^{\mathrm{MR}} / \mathrm{HC}^{-\mathrm{RI}}$, absence of mycorrhizal roots in the $\mathrm{RC}$ and $R$. irregularis

$\mu \mathrm{mol} \mathrm{g}^{-1}$ fresh weight, while in exudates they were $20.1 \pm$ $1.9,15.7 \pm 0.7$, and $0.17 \pm 0.07 \mu \mathrm{M}$, respectively.

\section{Experiment 2: Impact of $R$. irregularis on metabolism and phosphatase production in $R$. aquatilis}

The phosphatase activities and $\mathrm{P}$ concentrations in the MSR medium of the $\mathrm{HC}$ were measured after $72 \mathrm{~h}$ of culture of $R$. aquatilis in the absence or presence of the extraradical hyphae of $R$. irregularis (ANOVA results are shown in Table S2a). No significant differences were noticed in phosphatase activities (Fig. 1a, b) and $\mathrm{P}$ concentrations (Fig. 1c, d) between the two control treatments $\left(\mathrm{RC}^{-\mathrm{MR}} / \mathrm{HC}\right.$ ${ }_{-\mathrm{RI}}$ and $\left.\mathrm{RC}^{+\mathrm{MR}} / \mathrm{HC}^{-\mathrm{RI}}\right)$. Acid phosphatase and alkaline phosphatase activities were significantly larger $(P<0.05)$ in the presence of extraradical hyphae in the $\mathrm{HC}$ (i.e., $\mathrm{RC}^{+\mathrm{MR}}$ / $\mathrm{HC}^{+\mathrm{RI}}$ treatment) (Fig. 1a, b) and the inorganic $\mathrm{P}$ and phytate-P concentrations significantly smaller $(P<0.05)$ as compared to the two control treatments (Fig. 1c, d).

The expression of putative sugar transporter genes was measured in the $R$. aquatilis grown in the $\mathrm{HC}$ in the absence or presence of the extraradical hyphae (i.e., $\mathrm{RC}^{+\mathrm{MR}} / \mathrm{HC}^{+\mathrm{RI}}$ treatment) (ANOVA results are shown in Table S2b). The expression of putative trehalose transporter gene treT was not detected in any treatment, while the other two putative sugar transporter genes (i.e., putative fructose transporter

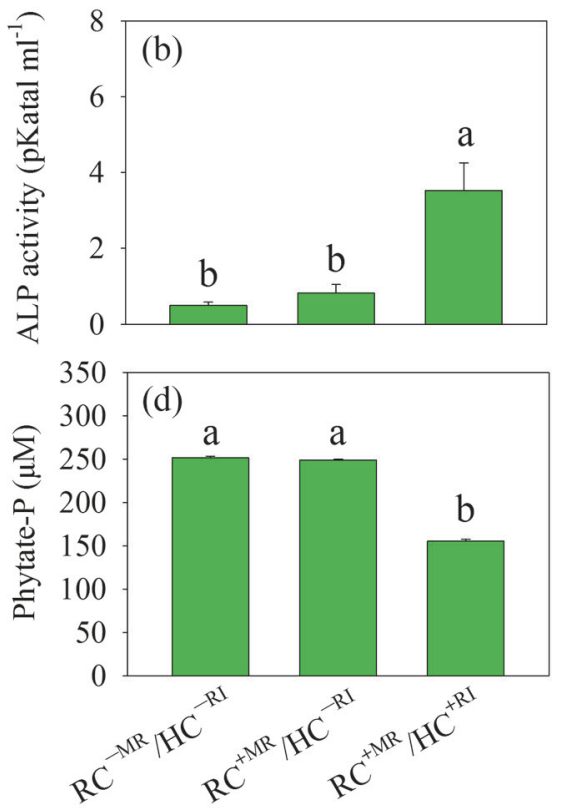

in the $\mathrm{HC} ; \mathrm{RC}^{+\mathrm{MR}} / \mathrm{HC}^{-\mathrm{RI}}$, presence of mycorrhizal roots in the $\mathrm{RC}$ but without proliferation of $R$. irregularis in the $\mathrm{HC} ; \mathrm{RC}^{+\mathrm{MR}} / \mathrm{HC}^{+\mathrm{RI}}$, presence of mycorrhizal roots in the $\mathrm{RC}$ and proliferation of $R$. irregularis in the HC. RC root compartment, HC hyphal compartment, MR mycorrhizal roots, RI $R$. irregularis

gene fruT and putative glucose transporter gene gluT) were detected in all treatments and at all observation times (Fig. 2a, b). No significant differences were noticed in gene expression between the two controls, except at $72 \mathrm{~h}$ for fruT and gluT. In the presence of the extraradical hyphae in the $\mathrm{HC}$ (i.e., $\mathrm{RC}^{+\mathrm{MR}} / \mathrm{HC}^{+\mathrm{RI}}$ treatment), the expression of fruT was the greatest at $1 \mathrm{~h}$, was significantly smaller $(P<0.05)$ at $6 \mathrm{~h}$, and the following times and did not differ significantly between $6,12,24,48$, and $72 \mathrm{~h}$ (Fig. 2a). The expression of gluT was the smallest at $1 \mathrm{~h}$ and then gradually increased until $72 \mathrm{~h}$ (Fig. 2b). Compared with the controls, the expression of fruT in the $\mathrm{RC}^{+\mathrm{MR}} / \mathrm{HC}^{+\mathrm{RI}}$ treatment was significantly greater $(P<0.05)$ at $1 \mathrm{~h}$ but smaller at $6,12,24,48$, and $72 \mathrm{~h}$; the expression of gluT in the $\mathrm{RC}^{+\mathrm{MR}} / \mathrm{HC}^{+\mathrm{RI}}$ treatment was only significantly greater $(P<0.05)$ at $6,12,24,48$, and $72 \mathrm{~h}$ and did not differ from the controls at $1 \mathrm{~h}$.

The expression of five phosphatase genes expressing exuded enzymes (i.e., phy, acpl, acp2, acp3, and alp) was measured to study the phosphatase production in $R$. aquatilis (ANOVA results are shown in Table S2b). Besides the expression of $a c p 1$ at $24 \mathrm{~h}$ and $a c p 3$ at $6 \mathrm{~h}$, no significant difference was noticed in the expression of genes between the two control treatments. Whatever the harvest time, the expression of phy was significantly greater $(P<0.05)$ in the $\mathrm{RC}^{+\mathrm{MR}} / \mathrm{HC}^{+\mathrm{RI}}$ treatment as compared to the control treatments (Fig. 2c), while the expression of $a c p 1, a c p 2$, and $a l p$ 

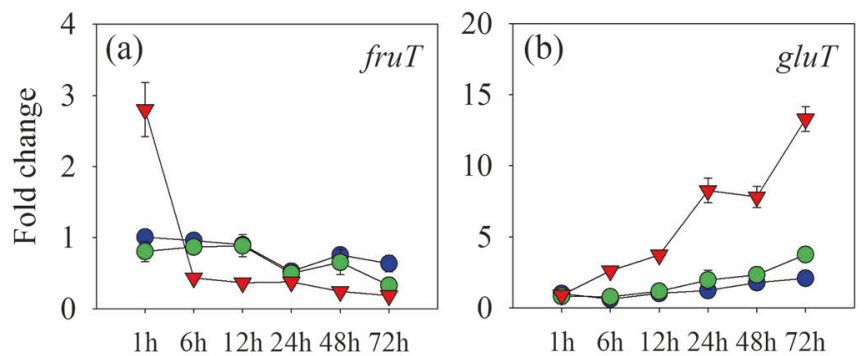

1h $6 \mathrm{~h} 12 \mathrm{~h} 24 \mathrm{~h} 48 \mathrm{~h} 72 \mathrm{~h}$
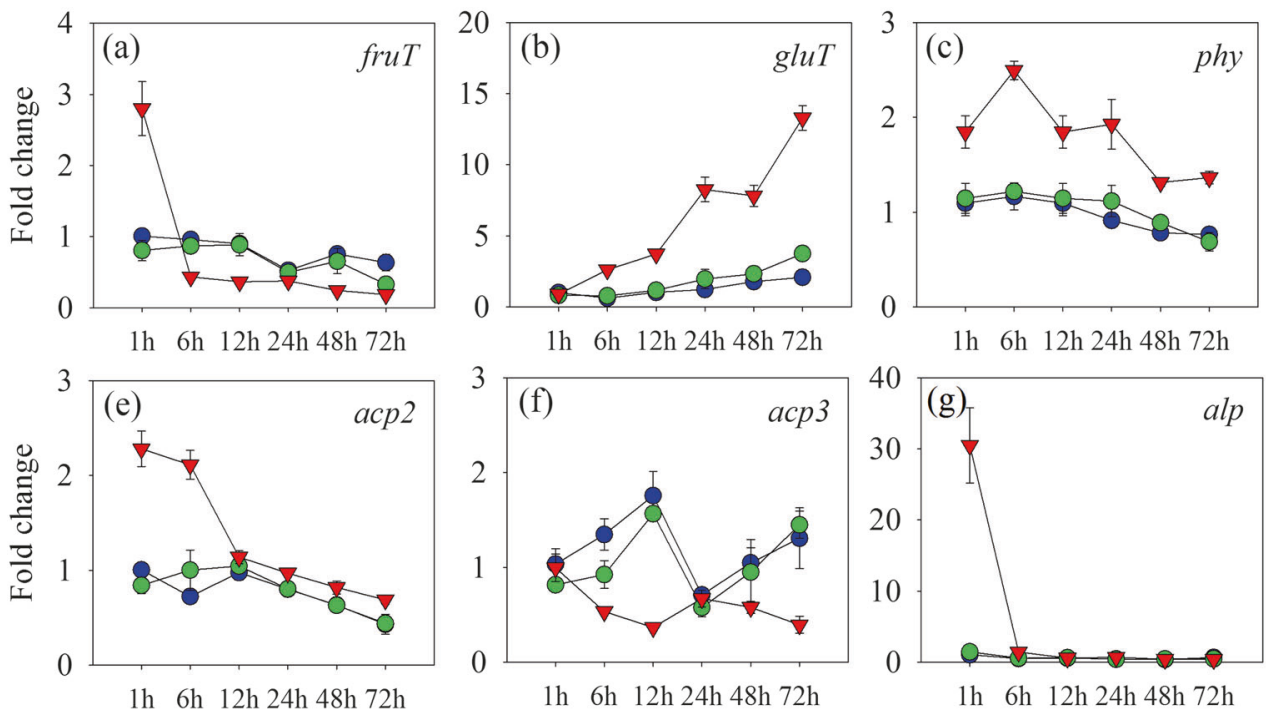

1h $6 \mathrm{~h} 12 \mathrm{~h} 24 \mathrm{~h} 48 \mathrm{~h} 72 \mathrm{~h}$

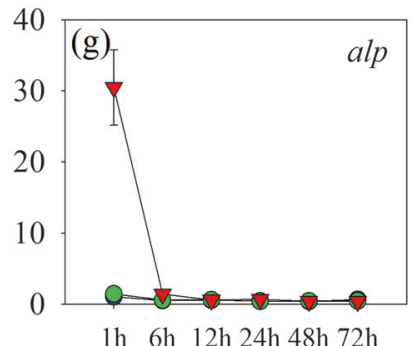

$-\mathrm{RC}^{-\mathrm{MR}} / \mathrm{HC}^{-\mathrm{RI}}$
$-\mathrm{RC^{+MR }} / \mathrm{HC}^{-\mathrm{RI}}$
$\longrightarrow-\mathrm{RC}^{+\mathrm{MR}} / \mathrm{HC}^{+\mathrm{RI}}$

1h 6 h $12 \mathrm{~h} 24 \mathrm{~h} 48 \mathrm{~h} 72 \mathrm{~h}$

$\mathrm{HC} ; \mathrm{RC}^{+\mathrm{MR}} / \mathrm{HC}^{-\mathrm{RI}}$, presence of mycorrhizal roots in the $\mathrm{RC}$ but without proliferation of $R$. irregularis in the $\mathrm{HC} ; \mathrm{RC}^{+\mathrm{MR}} / \mathrm{HC}^{+\mathrm{RI}}$, presence of mycorrhizal roots in the $\mathrm{RC}$ and proliferation of $R$. irregularis in the HC. RC root compartment, HC hyphal compartment, RA $R$. aquatilis, MR mycorrhizal roots, RI R. irregularis

and phosphatase genes (acpl and alp). Firstly, the expression of fruT was estimated 1 and $6 \mathrm{~h}$ after growth of $R$. aquatilis in liquid MSR medium in the absence $(0 \mu \mathrm{M})$ or in presence of $5,20,100 \mu \mathrm{M}$, or $1 \mathrm{mM}$ fructose added to the medium. At $1 \mathrm{~h}$, the expression of fruT was significantly greater $(P<0.05)$ in the presence of $20,100 \mu \mathrm{M}$, and $1 \mathrm{mM}$ fructose as compared to the presence of 0 and $5 \mu \mathrm{M}$ fructose, while at $6 \mathrm{~h}$, significant difference was only noticed in the presence of $1 \mathrm{mM}$ fructose as compared to the other concentrations (Fig. 4a). The expression of acpl and alp showed the same patterns compared to the expression of fruT in response to different concentrations of fructose added to the MSR medium (Fig. 4b, c). In addition, the linear regression analysis showed a significant positive relation between the expression of fruT and acpl (Fig. 4d) or alp (Fig. 4e).

Secondly, the influence of glucose at $20 \mu \mathrm{M}$ on the phosphatase production in $R$. aquatilis was tested. Glucose at $20 \mu \mathrm{M}$ had no impact on the expression of fruT at 1 and 6 h (Fig. 5a). Similarly, $20 \mu \mathrm{M}$ glucose did not significantly increase the expression of acpl (Fig. 5b) and alp (Fig. 5c) as compared to the treatment without $(0 \mu \mathrm{M})$ glucose.

\section{Experiment 3: Relationship between phosphatase gene expression and uptake of fructose and glucose in $R$. aquatilis}

Because putative trehalose transporter gene treT was not detected, we restricted our observations to the impact of fructose and glucose on phosphatase production in $R$. aquatilis, and to the relationship between the expression of these two putative sugars transporter gene (fruT and gluT)

\section{Experiment 4: Influence of fructose and glucose on growth and phosphatase activities of $R$. aquatilis}

The bacterial growth increased from 0 to $24 \mathrm{~h}$ or 0 to $12 \mathrm{~h}$ in the presence of $1 \mathrm{mM}$ fructose and glucose, respectively, and then remained unchanged. Fructose at $1 \mathrm{mM}$ had a stronger effect on stimulating bacterial growth than glucose at the same concentration (Fig. 6a). At 7 days, the presence 
Fig. 3 Expression of $\mathbf{a}, \mathbf{b}$ key genes in cell division ( $f$ st $A$ and $f s t Z)$ and $\mathbf{c}, \mathbf{d}$ type II $(g s p F)$ and type IV (vib8) secretory system of $R$. aquatilis harvested from the $\mathrm{HC}$ of the Petri plates at different time points in experiment 2. Data are mean of four replicates. $\mathrm{RC}^{-\mathrm{MR}} / \mathrm{HC}^{-\mathrm{RI}}$, absence of mycorrhizal roots in the $\mathrm{RC}$ and $R$. aquatilis in the $\mathrm{HC} ; \mathrm{RC}^{+\mathrm{MR}} / \mathrm{HC}^{-\mathrm{RI}}$, presence of mycorrhizal roots in the $\mathrm{RC}$ but without proliferation of $R$. aquatilis in the $\mathrm{HC} ; \mathrm{RC}^{+\mathrm{MR}} / \mathrm{HC}$ ${ }^{+\mathrm{RI}}$, presence of mycorrhizal roots in the $\mathrm{RC}$ and proliferation of $R$. aquatilis in the HC. RC root compartment, $\mathrm{HC}$ hyphal compartment, RA R. aquatilis, $\mathrm{RI} R$. irregularis
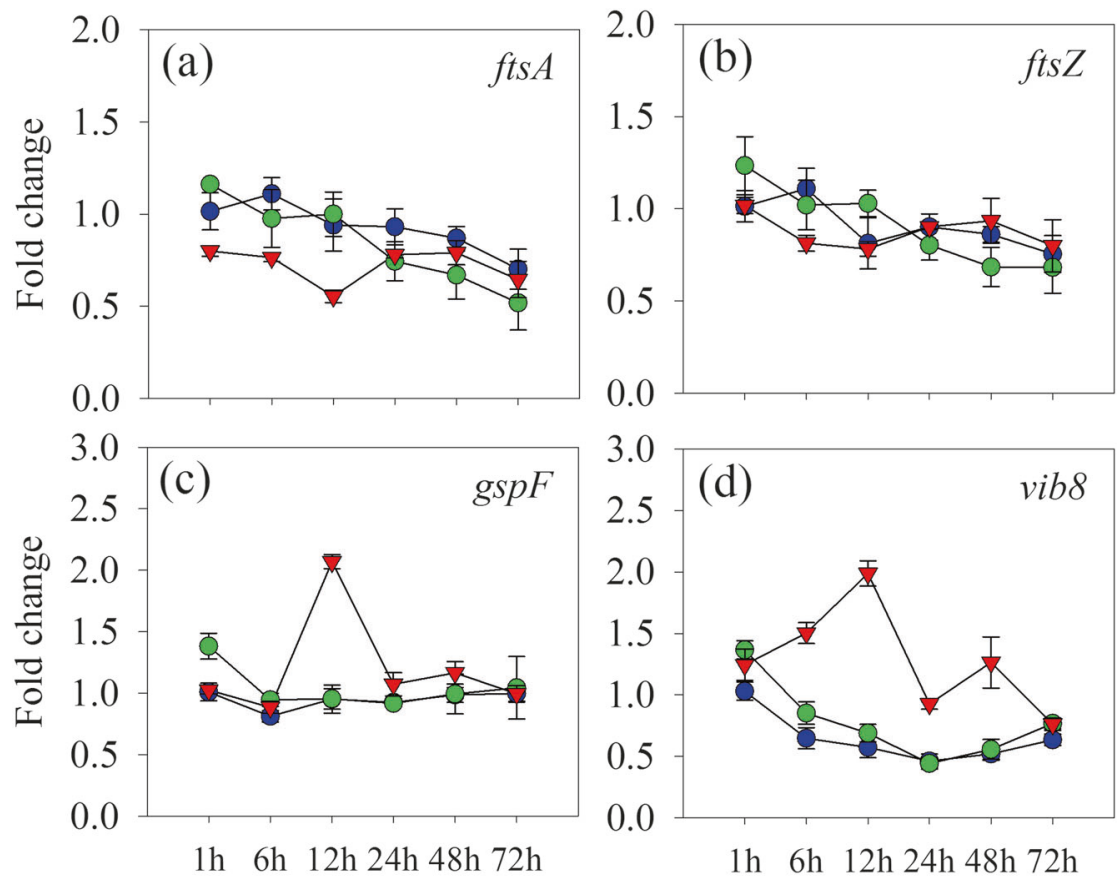

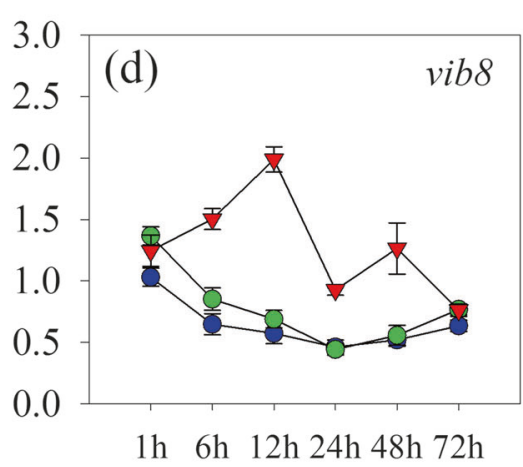

$$
-\mathrm{RC}^{-\mathrm{MR}} / \mathrm{HC}^{-\mathrm{RI}}-\mathrm{O} \mathrm{RC}^{+\mathrm{MR}} / \mathrm{HC}^{-\mathrm{RI}} \rightarrow-\mathrm{RC}^{+\mathrm{MR}} / \mathrm{HC}^{+\mathrm{RI}}
$$

of fructose at $100 \mu \mathrm{M}$ and $1 \mathrm{mM}$ significantly increased $(P$ $<0.05)$ both the acid and alkaline phosphatase activities, while this was not the case in presence of glucose (Fig. 6b, c).

\section{Experiment 5: Influence of $R$. aquatilis on genes expression in the extraradical hyphae of $R$. irregularis}

The proliferation of extraradical hyphae in the HC (i.e., the $+\mathrm{RI}+\mathrm{RA}$ treatment) of the plant in vitro culture system influenced the expression of putative sugar transporters and phosphatase genes of $R$. aquatilis harvested $6 \mathrm{~h}$ after plating the bacteria in the extraradical hyphae, as compared to the absence of $R$. irregularis (i.e., the $-\mathrm{RI}+\mathrm{RA}$ treatment). In the presence of extraradical hyphae, the expression of fruT was significantly upregulated by 0.6 fold $(P<0.05)$ and no difference was noticed in the expression of gluT as compared to the $-\mathrm{RI}+\mathrm{RA}$ treatment (Fig. 7a). The expression of acp 1, acp 2, and alp was significantly upregulated by 4.2 , 0.8 , and 4.0 fold $(P<0.05)$, respectively, in the presence of extraradical hyphae in the HC (Fig. 7b). In this plant, in vitro culture experiment, the increased expression of fruT was also accompanied by a significantly increased expression of acpl and alp.

In addition, the presence of $R$. aquatilis in the HC (i.e., the $+\mathrm{RI}+\mathrm{RA}$ treatment) stimulated the expression of the phosphate transporter gene GintPT and polyP synthesis gene $V t c 4 p$ in the extraradical hyphae of $R$. irregularis as compared to the absence of $R$. aquatilis (i.e., the +RI-RA treatment): the expression of GintPT and Vtc4p was significantly upregulated by 0.7 and 0.5 fold $(P<0.05)$, respectively (Fig. 7c).

\section{Discussion}

During evolution with plants, AMF have lost the genes encoding proteins involved in saprotrophic function [35], which means that they cannot directly breakdown soil organic matter [11, 36]. For instance, AMF cannot utilize phytate-P directly since they are unable to secrete phytases [35]. Part of the inorganic $P$ available to the AMF is released from the enzymatic activities of microbes which are able to decompose organic matter [11]. Microbes may thrive in the close vicinity of AMF forming communities on the surface of the extraradical hyphae. They intimately cooperate with AMF by providing inorganic nutrients released from the decomposition of organic matter in exchange for $\mathrm{C}$ exuded by the hyphae [15]. The mechanisms by which these exudates trigger $\mathrm{P}$ mineralization process in bacteria and the potential candidates that act as eliciting compounds are still unknown. In the present study, we hypothesized that sugars released by AMF hyphae are not only nutrients for the bacterium [15] but also signal molecules to trigger $\mathrm{P}$ mineralization by the bacterium, thus indirectly promoting the acquisition of the mineralized $\mathrm{P}$ by the hyphae of the fungus. 

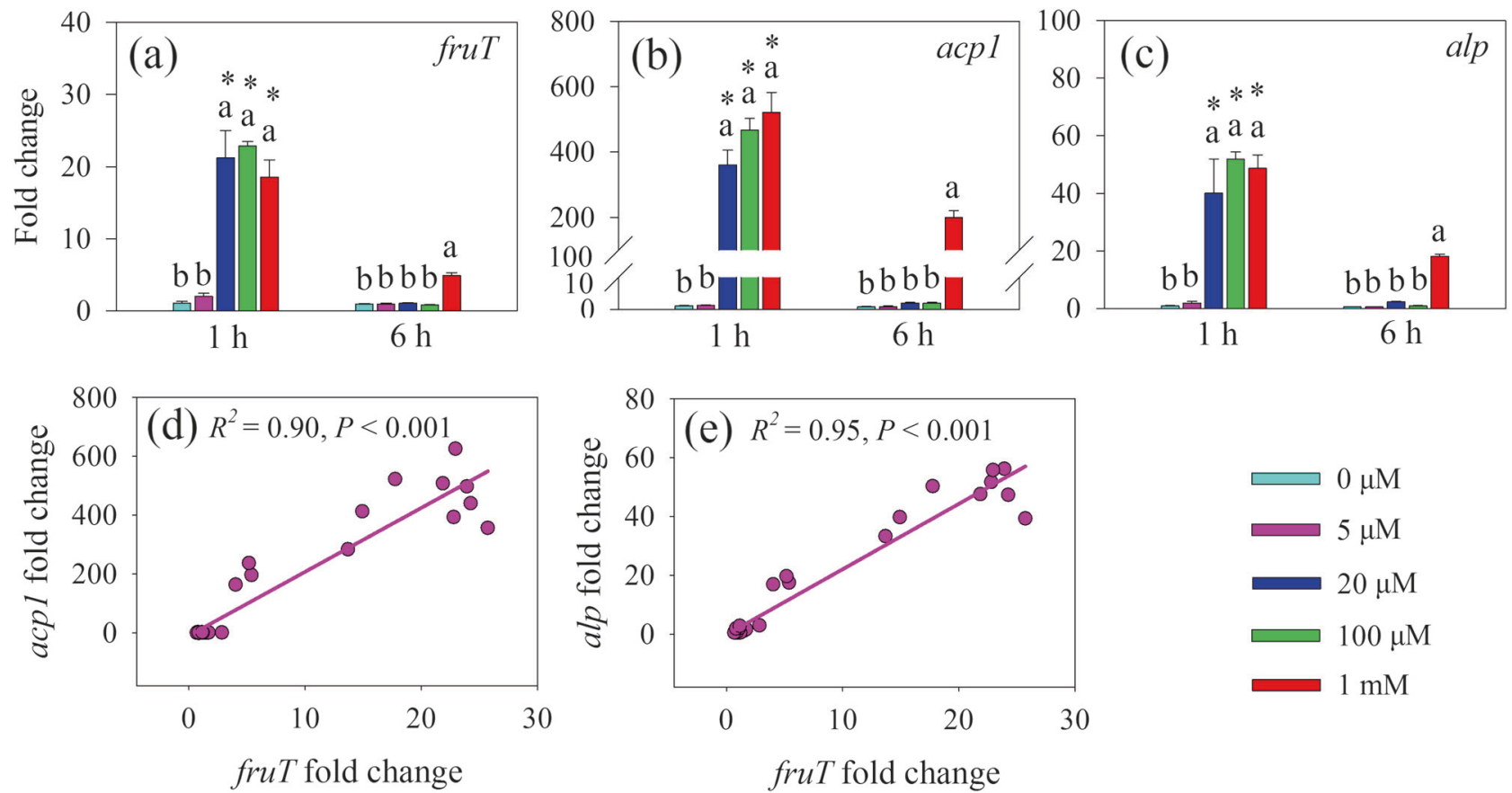

Fig. 4 Expression of a putative fructose transporter gene (fruT) and $\mathbf{b}$, c phosphatase genes (acpl and alp) of $R$. aquatilis growing in the liquid MSR medium containing 5, 20, $100 \mu \mathrm{M}$, or $1 \mathrm{mM}$ fructose or without $(0 \mu \mathrm{M})$ this sugar harvested at 1 and $6 \mathrm{~h}$ in experiment 3 . The associations between the expression of fruT and $\mathbf{d}$ acpl $\left(R^{2}=0.90 ; P\right.$ $<0.001)$ and e alp $\left(R^{2}=0.95 ; P<0.001\right)$ of $R$. aquatilis were

analyzed. Histograms with the same letter do not differ significantly $(P \geq 0.05$; Tukey's HSD test; $n=3)$ among five concentrations of fructose at the same harvest time point and asterisks indicate significant $(P<0.05 ; t$-test $)$ differences between two harvest time points at the same fructose concentration

To test this hypothesis, we first determined the ability of the extraradical hyphae to exude fructose, glucose, and trehalose. These sugars were detected inside the extraradical hyphae and as exudates, which confirmed the result of Bharadwaj et al. [23]. Trehalose was detected at a larger concentration than fructose but at a smaller concentration than glucose inside the hyphae (i.e., $75.6 \pm 32.8,263.9 \pm$ 106.7, and $188.6 \pm 84.5 \mu \mathrm{mol} \mathrm{g}^{-1}$ fresh weight for fructose, glucose, and trehalose, respectively), while its concentration in the exudates was the smallest as compared to fructose and glucose (i.e., $20.1 \pm 1.9,15.7 \pm 0.7$, and $0.17 \pm 0.07 \mu \mathrm{M}$ for fructose, glucose, and trehalose, respectively). To exclude the possibility that the sugars were released directly from the roots in the $\mathrm{RC}$ and diffused inside the medium to the hyphae and then by capillarity from RC to $\mathrm{HC}$ via the hyphae, $5 \mathrm{~mm}$ medium was removed in the $\mathrm{RC}$ along the plastic barrier. A mechanism of diffusion via the sole medium from the RC to $\mathrm{HC}$ was thus totally excluded. Transport of sugars via the surface of hyphae via capillary movement could also most probably been discounted also, because the hyphae (in the $5 \mathrm{~mm}$ medium gap) developed in the air and water potential on their surface should be drastically reduced, decreasing any possibility for capillary movement. If the transport of sugars via the surface of the hyphae can thus not be formally excluded, it is obvious that the main transport, in our experimental conditions, has

taken place through the lumen of the hyphae. Finally, it has been shown that the extraradical hyphae of AMF are unable to take up exogenous glucose and fructose [19-21], therefore excluding the possible uptake by the extraradical hyphae of hexoses released by the roots in the medium and their direct transport inside the hyphae. Collectively, our results demonstrate that fructose, glucose, and trehalose are exuded by the AMF hyphae.

The molecular response of the PSB $R$. aquatilis to the exudation of fructose, glucose, and trehalose was then investigated. As suggested by gene expression results, only fructose and glucose were transferred into $R$. aquatilis within the $72 \mathrm{~h}$ of experiment. The absence of detectable gene expression of putative trehalose transporter was curious because $R$. aquatilis is able to use this sugar [37]. One possible explanation is that trehalose may not be the true substrate of the studied gene-encoded protein and other putative sugar transporters may have this role. Another possible explanation is that the bacterium shows a preference for the absorption of the other two sugars over the 72-h study period. This was corroborated by the gene expression analysis indicating a preference of $R$. aquatilis for fructose first and then glucose. In addition, when $R$. aquatilis was cultured with fructose or glucose at the same concentration (i.e., $1 \mathrm{mM}$ ) during $72 \mathrm{~h}$, the optical density $\left(\mathrm{OD}_{590}\right)$ increased faster in the presence of fructose than in 

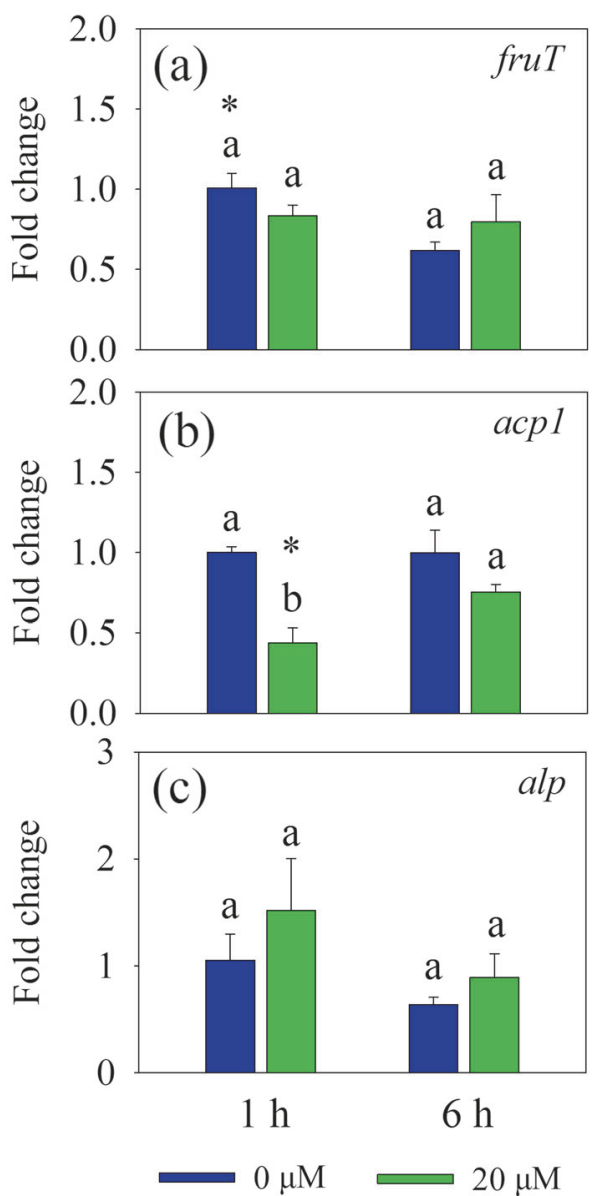

Fig. 5 Expression of a putative fructose transporter gene ( $f r u T)$ and $\mathbf{b}$, c phosphatase genes (acpl and alp) of $R$. aquatilis growing in the liquid MSR medium containing $20 \mu \mathrm{M}$ glucose or without $(0 \mu \mathrm{M})$ this sugar harvested at 1 and $6 \mathrm{~h}$ in experiment 3 . Histograms with the same letter do not differ significantly $(P \geq 0.05 ; t$-test $)$ among two sugar treatments at the same harvest time point and asterisks indicate significant $(P<0.05 ; t$-test $)$ differences between two harvest time points at the same sugar treatment

the presence of glucose. It supported our first hypothesis that sugars in the hyphal exudates are preferentially assimilated in sequential order by the bacterium. This mechanism was observed previously and has been named $\mathrm{C}$ catabolite repression [38]. Most bacteria can selectively use substrates from a mixture of different $\mathrm{C}$ sources [39]. The presence of preferred $\mathrm{C}$ sources (glucose is normally the preferred $\mathrm{C}$ for the bacteria [39]) prevents the expression, and often also the activity, of catabolic systems that enable the use of secondary substrates [39]. This result may also support the changes of bacterial communities in the presence of AMF hyphae [40]. AMF release different sugars and carboxylates at different concentrations into the soil that will stimulate certain groups of bacteria having preferences for some sugars more than others. This results in a quantitative modification in the bacterial populations and thus in the change of community composition of bacteria in contact with the hyphae.

Within the short-term period of study (i.e., 4 weeks), we expected the sugars to be exuded principally by the extraradical hyphae and to a lesser extent via cell death of hyphae. According to the reciprocity theory, the sugars released by AMF may stimulate bacterial activity and thus the breakdown of organic compounds into inorganic nutrients directly available to the hyphae. Here, we hypothesized that the sugars released by the AMF and taken up by the bacteria may stimulate bacterial cell division (by providing $\mathrm{C}$ source) and phosphatase activities (by providing signal molecules). However, the expression of two key genes in cell division ( ftsA and ftsZ) was not stimulated by the presence of hyphae within the time frame of the experiment (from 1 to $72 \mathrm{~h}$ ), while within a period of 2 and 4 weeks growth, the expression of these genes was stimulated [15], suggesting that AMF did not visibly influence bacterial growth in the short term. Stimulation of the expression of phosphatase genes can also enhance phosphatase activity [41]. In our study, the expression of four phosphatase genes was significantly stimulated by the hyphae of the AMF. It supported our second hypothesis that the expression of genes encoding bacterial phosphatase production and exudation increased concomitantly with the uptake of specific sugars. Interestingly, the expression of fruT followed the same trend as acpl and alp: they increased significantly in bacteria at $1 \mathrm{~h}$ and then decreased at $6 \mathrm{~h}$. It seemed that the uptake of fructose may be responsible for the increase of acpl and alp expression, but the influence of other metabolites in the hyphal exudates could not be excluded. We then set different concentrations of fructose added to $R$. aquatilis in the Petri plates to test the effects of fructose uptake on the gene expression of acpl and alp. We noticed that the presence of fructose at a concentration ranging from $20 \mu \mathrm{M}$ (the approximate concentration detected in the hyphal exudates) to $1 \mathrm{mM}$ induced a greater expression of fruT, acp 1, and alp and the expression of fruT had a positive linear correlation with the expression of acpl and alp. Conversely, the presence of glucose at the concentration of $20 \mu \mathrm{M}$ (the approximate concentration detected in the hyphal exudates) did not increase the gene expression of acpl and alp. These results clearly demonstrate that the uptake of fructose by $R$. aquatilis triggered the expression of phosphatase genes. After being transferred across the membrane of $R$. aquatilis, fructose was phosphorylated to fructose 1-phosphate [42], which may serve as a signal molecule to stimulate the expression of other genes. Previous studies have shown that fructose-1-phosphate is the preferred effector of the catabolite repressor/activator, which can stimulate the expression of other genes in the soil bacterium Pseudomonas putida [42]. In our study, the fructose secreted by the fungus triggered the gene 
Fig. 6 a Bacterial growth at 0,6 , $12,24,48$, and $72 \mathrm{~h}$ and $\mathbf{b}, \mathbf{c}$ phosphatase activities in the medium at 7 days when $R$. aquatilis was grown in the liquid MSR medium without fructose or glucose (i.e., $0 \mu \mathrm{M}$ ) or containing $5,20,100 \mu \mathrm{M}$, or 1 $\mathrm{mM}$ of the sugars in experiment 4. Histograms with the same letter do not differ significantly $(P \geq 0.05$; Tukey's HSD test; $n$ $=3$ ) among the treatments
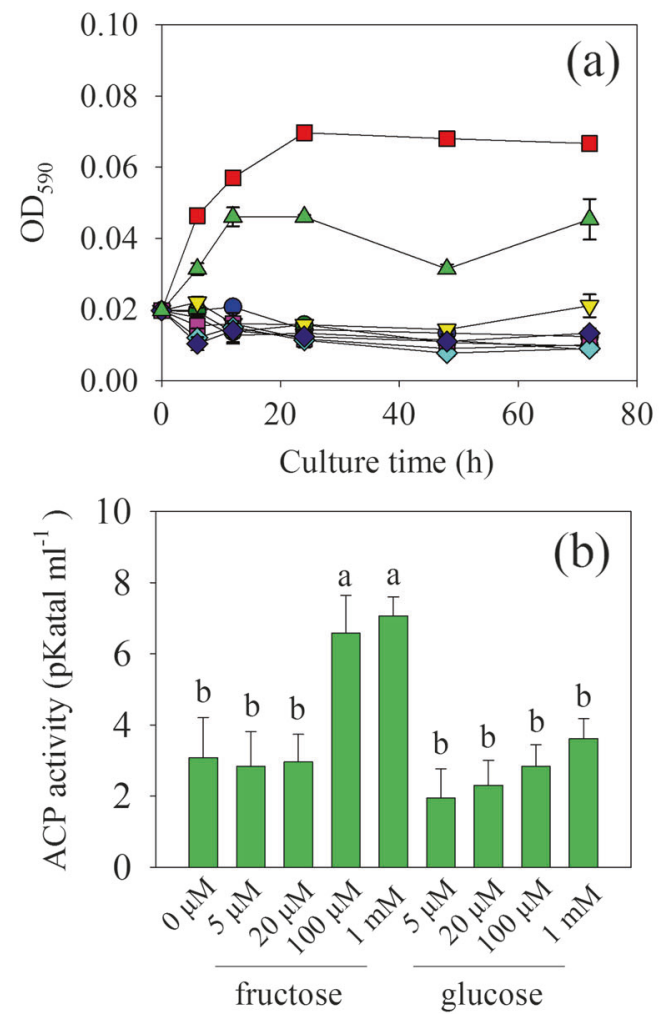
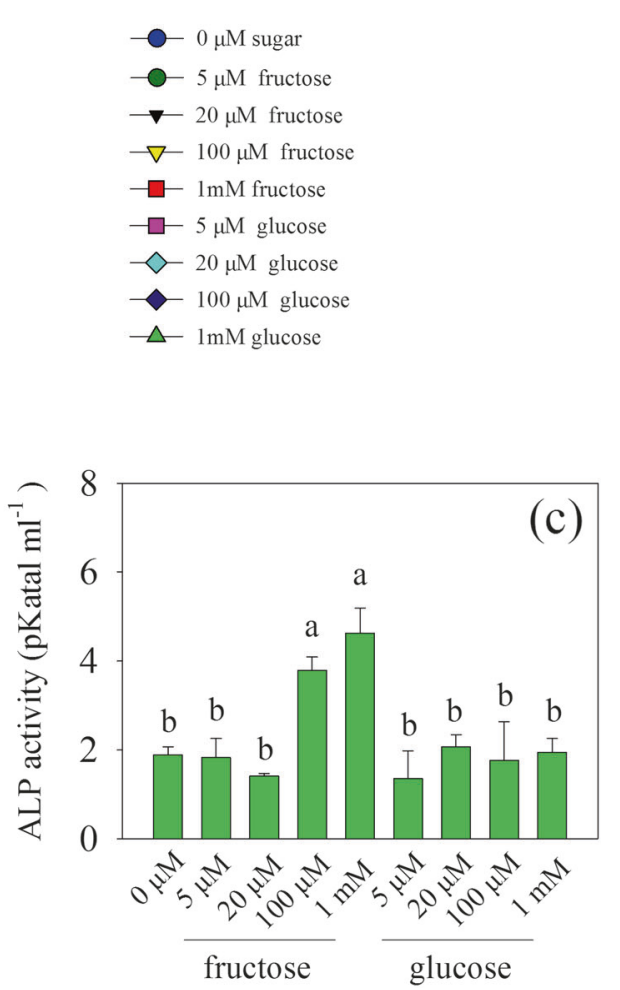

(a)

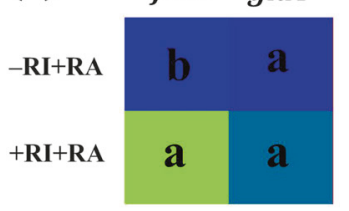

2.0

1.5

1.0 (b)

\begin{tabular}{|c|c|c|c|c|c|}
\hline$-\mathrm{RI}+\mathrm{RA}$ & a & $\mathbf{b}$ & b & $\mathbf{a}$ & b \\
\hline$+\mathbf{R I}+\mathbf{R A}$ & $\mathbf{a}$ & $\mathbf{a}$ & $\mathbf{a}$ & a & $\mathbf{a}$ \\
\hline
\end{tabular}

(c)

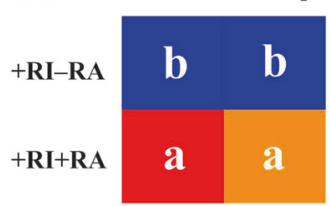

Fig. 7 Expression of a putative sugar transporter genes (fruT and gluT) and b phosphatase genes (phy, acp1, acp2, acp3, and alp) of $R$. aquatilis, and c phosphate transporter gene GintPT and polyP synthesis gene Vtc4p of the extraradical hyphae of $R$. irregularis harvested from the hyphal compartment of the Petri plate at $6 \mathrm{~h}$ in experiment 5 . Different letters indicate significant difference $(P \geq 0.05 ; t$-test; $n=3)$ between the treatments of $-\mathrm{RI}+\mathrm{RA}$ and $+\mathrm{RI}+\mathrm{RA}$ or $+\mathrm{RI}-\mathrm{RA}$ and $+\mathrm{RI}+\mathrm{RA}$. $-\mathrm{RI}+\mathrm{RA}$, absence of $R$. irregularis but with $R$. aquatilis in the $\mathrm{HC}$; $+\mathrm{RI}-\mathrm{RA}$, presence of $R$. irregularis but without $R$. aquatilis in the $\mathrm{HC}$; $+\mathrm{RI}+\mathrm{RA}$, presence of both $R$. irregularis and $R$. aquatilis in the HC. HC hyphal compartment, RA $R$. aquatilis, RI $R$. irregularis expression of phosphatases of $R$. aquatilis and thus increased the phosphatase activity in the hyphosphere. Besides fructose, trehalose has been demonstrated to play roles as signal molecule [13] and glucose is normally a preferred substrate for bacterial growth [43], but there is no evidence that they could also stimulate the gene expression of phosphatases. Besides sugars, there are also other C-rich compounds, e.g., carboxylates, amino acids in the hyphal exudates [23], but whether they can play roles as signal molecules needs further investigation.

Only the phosphatases released from bacterial cells are involved in organic $\mathrm{P}$ hydrolyzation. We selected five secreted phosphatases whose exudation usually depends on type II and IV secretory systems [44, 45]. We tested the expression of two genes, i.e., gspF in type II and vibs in type IV secretory systems and found that they were stimulated by AMF at $12 \mathrm{~h}$ and 6 to $48 \mathrm{~h}$, respectively, which followed the increased expression of phosphatase genes. This suggested that AMF could increase the rate of phosphatase secretion by regulating the protein secretory systems in the bacterium.

The stimulated expression of phosphatase and secretory system genes may lead to higher phosphatase activity outside the bacterial cells. This was demonstrated by the significantly greater acid and alkaline phosphatase activities in the MSR medium sampled at $72 \mathrm{~h}$, which was in agreement with our previous result at 2 and 4 week [15]. The increased phosphatase activities then enhanced phytate $\mathrm{P}$ 
Fig. 8 Schematic representation of the reciprocal rewards of carbon $(\mathrm{C})$ and phosphorus $(\mathrm{P})$ between the arbuscular mycorrhizal fungus (AMF) $R$. irregularis and the phosphatesolubilizing bacterium (PSB) $R$. aquatilis. ST sugar transporter, fruT fructose transporter, gluT glucose transporter, PT phosphate transporter, PSS protein secretory system, Pase phosphatase, Pi inorganic P, Po organic $\mathrm{P}$

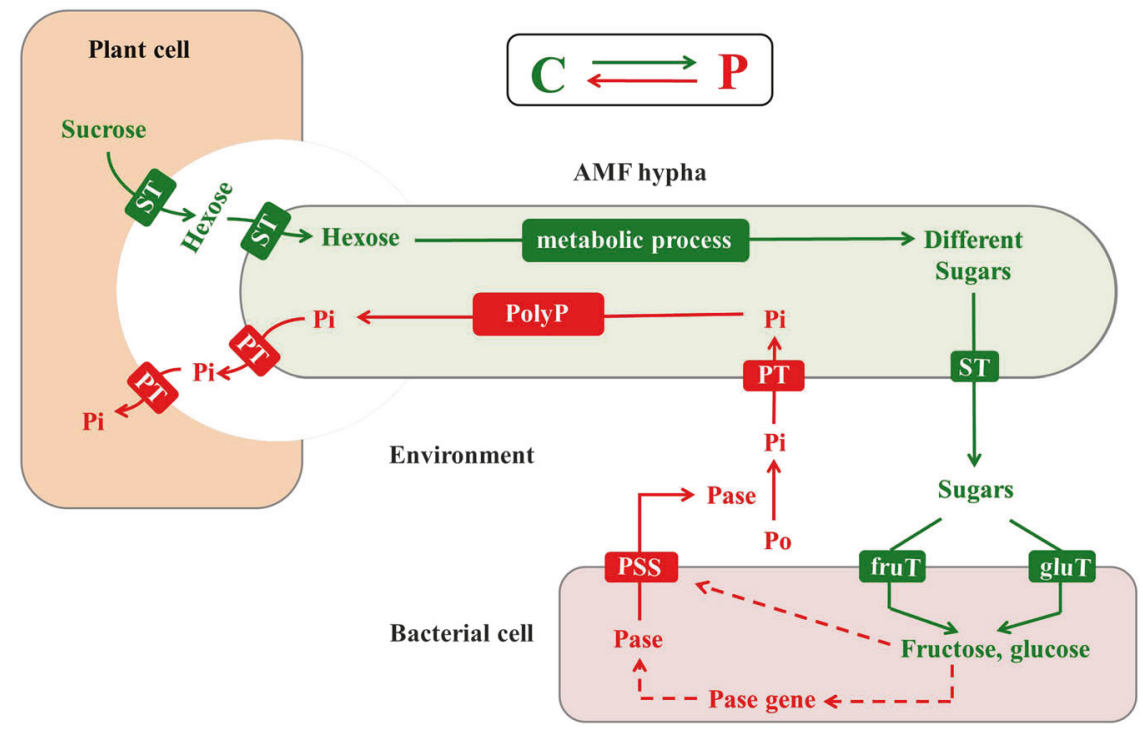

hydrolyzation. The concentration of phytate $\mathrm{P}$ decreased by $120 \mu \mathrm{M}$ in the presence of the AMF, and the decrease due to $R$. aquatilis immobilization was only $15 \mu \mathrm{M}$, which meant that most of the mobilized inorganic $\mathrm{P}$ was taken up by the AMF hyphae. The increased $P$ uptake may be accompanied with more high-affinity $\mathrm{P}$ transporters in the extraradical hyphae. This was demonstrated by the significantly higher GintPT expression when AMF was present in the whole plant system. In addition, the expression of polyP synthesis gene $V t c 4 p$ was also increased, which indicated that the polyP synthesis process in the vacuoles was stimulated. These results clearly supported that AMF acquired their available $\mathrm{P}$ by stimulating the activity of PSB and supported our third hypothesis that the genes involved in the processes of phosphate transfer and polyP synthesis in the extraradical hyphae of the AMF was enhanced by the presence of the bacteria.

\section{Conclusion}

Our results demonstrated for the first time the reciprocal rewards of $\mathrm{C}$ and $\mathrm{P}$ between the AMF $R$. irregularis and the PSB $R$. aquatilis, at transcriptional level (Fig. 8). The extraradical hyphae of $R$. irregularis released sugars into the environment. The sugars were taken up by $R$. aquatilis in different orders of preference: fructose first and then glucose. Fructose exuded by the fungus played a key role as signal compound and stimulated the expression of phosphatase genes in the bacterium. AMF also enhanced the efficiency of phosphatase secretion to the environment by regulating the protein secretory systems in the bacterium. As a result, the phosphatase activity in the environment was increased and promoted the hydrolyzation of organic P.
More inorganic $\mathrm{P}$ was thus available for the AMF and the processes relative to $\mathrm{P}$ uptake and metabolism were stimulated. Considering the ubiquity of AMF and their associated microbes [9, 46], our finding could help explaining the complex processes occurring in the rhizosphere that ultimately contribute to one of the acknowledged beneficial effects of arbuscular fungi to their host plants: the provision of soil phosphorus.

Acknowledgements We thank associate professor Yanbin Guo from College of Resources and Environmental Sciences, China Agricultural University, for providing the bacterial strain Rahnella aquatilis HX2. This study is supported by National Key R\&D Program of China (2017YFD0200200) and the National Natural Science Foundation of China (U1703232, 31701998). We further thank the China Scholarship Council (File No. 201306350121) for providing a scholarship for LZ.

Author contributions LZ, GF and SD conceived and designed the study. LZ undertook the research and analyzed and interpreted the data. LZ, GF and SD discussed the results. GF and SD revised the manuscript written by LZ. GF and SD provided funding for this study.

\section{Compliance with ethical standards}

Conflict of interest The authors declare that they have no conflict of interest.

Open Access This article is licensed under a Creative Commons Attribution 4.0 International License, which permits use, sharing, adaptation, distribution and reproduction in any medium or format, as long as you give appropriate credit to the original author(s) and the source, provide a link to the Creative Commons license, and indicate if changes were made. The images or other third party material in this article are included in the article's Creative Commons license, unless indicated otherwise in a credit line to the material. If material is not included in the article's Creative Commons license and your intended use is not permitted by statutory regulation or exceeds the permitted use, you will need to obtain permission directly from the copyright 
holder. To view a copy of this license, visit http://creativecommons. org/licenses/by/4.0/.

\section{References}

1. Rainey PB, De Monte S. Resolving conflicts during the evolutionary transition to multicellular life. Annu Rev Ecol Evol Syst. 2014;45:599-620.

2. Dorsky RI, Itoh M, Moon RT, Chitnis A. Two tcf3 genes cooperate to pattern the zebrafish brain. Development. 2003;130:1937-47.

3. Nowak MA. Five rules for the evolution of cooperation. Science. 2006;314:1560-3.

4. Redecker D, Kodner R, Graham LE. Glomalean fungi from the Ordovician. Science. 2000;289:1920-1.

5. Bever JD, Richardson SC, Lawrence BM, Holmes J, Watson M. Preferential allocation to beneficial symbiont with spatial structure maintains mycorrhizal mutualism. Ecol Lett. 2009;12:13-21.

6. Kiers ET, Duhamel M, Beesetty Y, Mensah JA, Franken O, Verbruggen E, et al. Reciprocal rewards stabilize cooperation in the mycorrhizal symbiosis. Science. 2011;333:880-2.

7. Miller RM, Jastrow JD, Reinhardt DR. External hyphal production of vesicular-arbuscular mycorrhizal fungi in pasture and tallgrass prairie communities. Oecologia. 1995;103:17-23.

8. Scheublin TR, Sanders IR, Keel C, van der Meer JR. Characterisation of microbial communities colonising the hyphal surfaces of arbuscular mycorrhizal fungi. ISME J. 2010;4:752-63.

9. Agnolucci M, Battini F, Cristani C, Giovannetti M. Diverse bacterial communities are recruited on spores of different arbuscular mycorrhizal fungal isolates. Biol Fertil Soils. 2015;51:379-89.

10. Feng G, Su YB, Li XL, Wang H, Zhang FS, Tang CX, et al. Histochemical visualization of phosphatase released by arbuscular mycorrhizal fungi in soil. J Plant Nutr. 2002;25:969-80.

11. Zhang L, Fan J, Ding X, He X, Zhang F, Feng G. Hyphosphere interactions between an arbuscular mycorrhizal fungus and a phosphate solubilizing bacterium promote phytate mineralization in soil. Soil Biol Biochem. 2014;74:177-83.

12. Wang F, Shi N, Jiang R, Zhang F, Feng G. In situ stable isotope probing of phosphate-solubilizing bacteria in the hyphosphere. $\mathrm{J}$ Exp Bot. 2016;67:1689-701.

13. Drigo B, Pijl AS, Duyts H, Kielak A, Gamper HA, Houtekamer MJ, et al. Shifting carbon flow from roots into associated microbial communities in response to elevated atmospheric $\mathrm{CO}_{2}$. Proc Natl Acad Sci USA. 2010;107:10938-42.

14. Kaiser C, Kilburn MR, Clode PL, Fuchslueger L, Koranda M, Cliff JB, et al. Exploring the transfer of recent plant photosynthates to soil microbes: mycorrhizal pathway vs direct root exudation. New Phytol. 2015;205:1537-51.

15. Zhang L, Xu M, Liu Y, Zhang F, Hodge A, Feng G. Carbon and phosphorus exchange may enable cooperation between an arbuscular mycorrhizal fungus and a phosphate-solubilizing bacterium. New Phytol. 2016;210:1022-32.

16. Böhringer J, Fischer D, Mosler G, Hengge-Aronis R. UDPglucose is a potential intracellular signal molecule in the control of expression of sigma S and sigma S-dependent genes in Escherichia coli. J Bacteriol. 1995;177:413-22.

17. Barrière C, Veiga-da-Cunha M, Pons N, Guedon E, van Hijum S, Kok J, et al. Fructose utilization in Lactococcus lactis as a model for low-GC gram-positive bacteria: its regulator, signal, and DNAbinding. J Bacteriol. 2005;187:3752-61.

18. Parniske M. Arbuscular mycorrhiza: the mother of plant root endosymbioses. Nat Rev Microbiol. 2008;6:763-75.
19. Pfeffer PE, Douds DD, Bécard G, Shachar-Hill Y. Carbon uptake and the metabolism and transport of lipids in an arbuscular mycorrhiza. Plant Physiol. 1999;120:587-98.

20. Douds DD, Pfeffer PE, Shachar-Hill Y. Application of in vitro methods to study carbon uptake and transport by AM fungi. Plant Soil. 2000;226:255-61.

21. Bücking H, Shachar-Hill Y. Phosphate uptake, transport and transfer by the arbuscular mycorrhizal fungus Glomus intraradices is stimulated by increased carbohydrate availability. New Phytol. 2005;165:899-912.

22. Dennis PG, Miller AJ, Hirsch PR. Are root exudates more important than other sources of rhizodeposits in structuring rhizosphere bacterial communities? FEMS Microbiol Ecol. 2010;72:313-27.

23. Bharadwaj DP, Alstrom S, Lundquist P-O. Interactions among Glomus irregulare, arbuscular mycorrhizal spore-associated bacteria, and plant pathogens under in vitro conditions. Mycorrhiza. 2012;22:437-47.

24. Guo Y, Jiao Z, Li L, Wu D, Crowley DE, Wang Y, et al. Draft genome sequence of Rahnella aquatilis strain $\mathrm{HX} 2$, a plant growth-promoting rhizobacterium isolated from vineyard soil in Beijing, China. J Bacteriol. 2012;194:6646-7.

25. Buysens C, de Boulois HD, Declerck S. Do fungicides used to control Rhizoctonia solani impact the non-target arbuscular mycorrhizal fungus Rhizophagus irregularis? Mycorrhiza. 2015;25:277-88.

26. St-Arnaud M, Hamel C, Vimard B, Caron M, Fortin JA. Enhanced hyphal growth and spore production of the arbuscular mycorrhizal fungus Glomus intraradices in an in vitro system in the absence of host roots. Mycol Res. 1996;100:328-32.

27. Duan L, Qi X, Chen M, Huang L. Application of metabolomics in the identification of Chinese herbal medicine. In: Qi X, Chen X, Wang Y, editors. Plant metabolomics: methods and applications. Beijing: Chemical Industry Press; 2015. p. 227-44.

28. Chi Z, Zheng Y, Jiang A, Chen S. Lipid production by culturing oleaginous yeast and algae with food waste and municipal wastewater in an integrated process. Appl Biochem Biotechnol. 2011;165:442-53.

29. Murphy J, Riley JP. A modified single solution method for the determination of phosphate in natural waters. Anal Chim Acta 1962;26:31-6.

30. Neumann G. Quantitative determination of acid phosphatase activity in the rhizosphere and on the root surface. In: Jones DL, editor. Handbook of methods used in rhizosphere research. Birmensdorf, Switzerland: Swiss Federal Research Institute WSL; 2006. p. 79-85.

31. Ririe KM, Rasmussen RP, Wittwer CT. Product differentiation by analysis of DNA melting curves during the polymerase chain reaction. Anal Biochem. 1997;245:154-60.

32. Voets L, Dupre de Boulois H, Renard L, Strullu DG, Declerck S. Development of an autotrophic culture system for the in vitro mycorrhization of potato plantlets. FEMS Microbiol Lett. 2005;248:111-8.

33. Fiorilli V, Lanfranco L, Bonfante P. The expression of GintPT, the phosphate transporter of Rhizophagus irregularis, depends on the symbiotic status and phosphate availability. Planta. 2013;237:1267-77.

34. Gonzàlez-Guerrero M, Benabdellah K, Valderas A, AzconAguilar C, Ferrol N. GintABCl encodes a putative ABC transporter of the MRP subfamily induced by $\mathrm{Cu}, \mathrm{Cd}$, and oxidative stress in Glomus intraradices. Mycorrhiza. 2010;20:137-46.

35. Tisserant E, Malbreil M, Kuo A, Kohler A, Symeonidi A, Balestrini R, et al. Genome of an arbuscular mycorrhizal fungus provides insight into the oldest plant symbiosis. Proc Natl Acad Sci USA. 2013;110:20117-22. 
36. Leigh J, Fitter AH, Hodge A. Growth and symbiotic effectiveness of an arbuscular mycorrhizal fungus in organic matter in competition with soil bacteria. FEMS Microbiol Ecol. 2011;76:428-38.

37. Chen F. Primary studies on biological control of grapevine crown gall by Rahnella aquatilis HX2. Beijing, China: China Agricultural University; 2007.

38. Deutscher J. The mechanisms of carbon catabolite repression in bacteria. Curr Opin Microbiol. 2008;11:87-93.

39. Görke B, Stülke J. Carbon catabolite repression in bacteria: many ways to make the most out of nutrients. Nat Rev Microbiol. 2008;6:613-24.

40. Nuccio EE, Hodge A, Pett-Ridge J, Herman DJ, Weber PK, Firestone MK. An arbuscular mycorrhizal fungus significantly modifies the soil bacterial community and nitrogen cycling during litter decomposition. Environ Microbiol. 2013;15:1870-81.

41. Rodríguez H, Fraga R. Phosphate solubilizing bacteria and their role in plant growth promotion. Biotechnol Adv. 1999;17:319-39.
42. Chavarría M, Durante-Rodriguez G, Krell T, Santiago C, Brezovsky J, Damborsky J, et al. Fructose 1-phosphate is the one and only physiological effector of the Cra (FruR) regulator of Pseudomonas putida. FEBS Open Bio. 2014;4:377-86.

43. Brückner R, Titgemeyer F. Carbon catabolite repression in bacteria: choice of the carbon source and autoregulatory limitation of sugar utilization. FEMS Microbiol Lett. 2002;209:141-8.

44. Christie PJ, Atmakuri K, Krishnamoorthy V, Jakubowski S, Cascales E. Biogenesis, architecture, and function of bacterial type IV secretion systems. Annu Rev Microbiol. 2005;59:451-85.

45. Cianciotto NP. Type II secretion: a protein secretion system for all seasons. Trends Microbiol. 2005;13:581-8.

46. Iffis B, St-Arnaud M, Hijri M. Petroleum hydrocarbon contamination, plant identity and arbuscular mycorrhizal fungal (AMF) community determine assemblages of the AMF sporeassociated microbes. Environ Microbiol. 2016;18:2689-704. 